\title{
Syntheses, characterization and binding strength of geopolymers: A review
}

\section{OLAWALE Margaret Damilola}

Department of Physical and Chemical Sciences, Faculty of Basic and applied Sciences, Elizade University, Ilara-Mokin, Nigeria

\section{Email address:}

margaret.olawale@elizadeuniversity.edu.ng

\section{To cite this article:}

OLAWALE Margaret Damilola. Syntheses, Characterization and Binding Strength of Geopolymers: A Review. International Journal of Materials Science and Applications. Vol. 2, No. 6, 2013, pp. 185-193. doi: 10.11648/j.ijmsa.20130206.14

\begin{abstract}
There exist a large number of raw materials sources rich in alumina and silicon with the potential for procuring geopolymers. Among the materials predominate fly ash, calcined clays, puzzolans, kaolins, illite/smectite, metakaolins and slags. Geopolymers results from the reaction of aluminosilicate powder with an alkaline silicate solution. It has been brought to lime light that geopolymer display several usefulness in thermal insulation, thermal shock refractories, production of low energy ceramic tiles, cements and concretes, high-tech composites for aircraft interior and automobile, high-tech resin systems, in radioactive and toxic waste containment, arts and decoration. Geopolymers are generally known to have high compressive strength, fire and acid attack resistance, low water absorption capacity and thermal conductivity. This paper describes different materials suitable for procurement of geopolymer and reviews the trend in the compressive strength and water absorption of different types of synthesized geopolymers. The findings of this study, shows that compressive strength of geopolymer increases with increase in concentration of sodium silicate as well as sodium hydroxide and water absorptivity of any geopolymer decreases with increase in concentration of sodium hydroxide, water glass and duration of the geopolymer curing time.
\end{abstract}

Keywords: Geopolymer, Clay, Slag, Compressive Strength

\section{Introduction}

\subsection{What is Geopolymer}

The term geopolymer was coined nearly three decades back by Davidovits (a French scientist) for alumino-silicate polymers formed in alkaline environment [1]. It is an inorganic, hardened cementitious paste which can be made from fly ash without Portland cement. Geopolymer is also known to be a term covering a class of synthetic aluminosilicate materials. It is a novel family of building materials, a new material for coatings and adhesives, new binders for fiber composites, waste encapsulation and new cement for concrete [2]. The chemical composition of geopolymer is somewhat similar to zeolites but with an amorphous microstructure.

Unlike ordinary Portland/pozzolanic cements, geopolymers do not form calcium-silicate-hydrates (CSHs) for matrix formation and strength, but utilize the polycondensation of silica and alumina precursors to attain structural strength.

Davidovits [1] elucidated a structural model of the geopolymer (poly-sialate-silox type formed by alkali activation of meta-kaolin). His elucidation assumed an essentially monolithic polymer similar to organic polymers. (Figure 1)

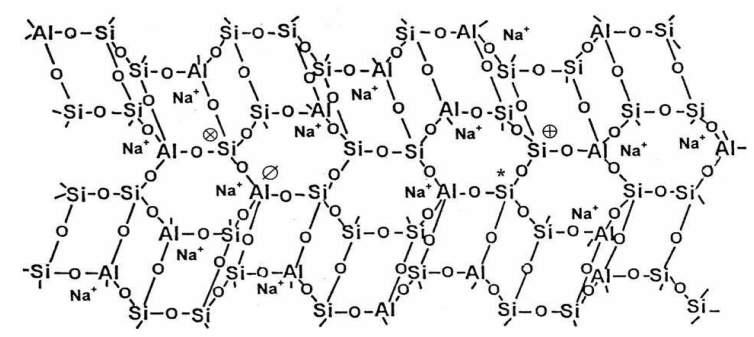

Figure 1. Davidovits model of geopolymer structure [1].

\subsection{Essences of Geopolymer}

Versatility of geopolymer can be measured from civil applications in term of high compressive strength for geopolymer cement and concrete, acid attack resistance $[3,4,5]$, quick repair of materials for ancient archeological structures, to interior of modern aircraft which make use of fire-resistant properties of geopolymer composites [6]. Due 
to the fact that geopolymer composites did not ignite, burn, or release any smoke even after extended heat flux. Therefore, they are suitable as aircraft cabin materials for cargo liners, ceiling, floor panels, partitions and sidewalls, stowage bins, and wire insulation $[7,8]$.

Most scientific and industrial disciplines, modern inorganic chemistry, physical chemistry, mineralogy, geology, analytical chemistry and in all types of engineering process technologies, exploit the versatility of geopolymer. Others potential applications of geopolymer includes: decorative stone artifacts, thermal insulation, lowtech building materials, low energy ceramic tiles, refractory items, thermal shock refractories, foundry applications, cements and concretes, composites for infrastructures repair and strengthening, high-tech composites for aircraft interior and automobile, high-tech resin systems, radioactive and toxic waste containment, arts and decoration, cultural heritage, archaeology and history of sciences[1,53]. It was also discovered that manufacturing of geopolymer composites, unlike Portland cement consume no energy. On the other hand, the use of waste products like fly ash, blast furnace slag etc for manufacture of geopolymers has led to tremendous waste encapsulation, by converting waste product into a useful product. An emission of $\mathrm{CO}_{2}$ from cement production is increasing at a much more rapid rate than all other industrial sources put together. Fabrication of Portland cement do generates $\mathrm{CO}_{2}$ through calcination of raw materials and fuel consumption [9]. It has been brought to lime light through calculation that 1 ton of Portland cement generates 1 ton of $\mathrm{CO}_{2}$ [9]. It is estimated that with demographic growth and industrialization, the pollution generated by Portland cement production in a few years will represent $17 \%$ of worldwide $\mathrm{CO}_{2}$ emissions (currently it is around 7\%). By the year 2015, a global $\mathrm{CO}_{2}$ emission from the manufacture of Portland cement is expected to be 3,500 million tonnes annually. Manufacturing geopolymeric cement generates five (5) times less $\mathrm{CO}_{2}$ than does the manufacture of Portland cement. Any country that converts to the manufacture of geopolymeric cement/concrete would eliminate $80 \%$ of the emissions generated from the cement and aggregates industries. Geopolymer features a $90 \%$ or greater reduction in carbon dioxide emission [10].

\subsection{Synthesis of Geopolymer}

Geopolymer can be fabricated with natural raw materials such as calcined clay, kaolin, metakaolin, smectite or with industrial wastes such as fly ash, slag that is rich in silicoaluminate. Based on the work of Cioffi et al., Geopolymers comprise of three classes of inorganic polymers that, depend on the silica/alumina ratio, and are based on the following three different monomeric units: (-Si-O-Al-O-), polysialate (PS), $\mathrm{SiO}_{2} / \mathrm{Al}_{2} \mathrm{O}_{3}=2 ;(-\mathrm{Si}-\mathrm{O}-\mathrm{Al}-\mathrm{O}-\mathrm{Si}-\mathrm{O}-)$, polysialatesiloxo (PSS), $\mathrm{SiO}_{2} / \mathrm{Al}_{2} \mathrm{O}_{3}=4$; (-Si-O-Al-O-Si$\mathrm{O}-\mathrm{Si}-\mathrm{O}-$ ), polysialatedisiloxo (PSDS), $\mathrm{SiO}_{2} / \mathrm{Al}_{2} \mathrm{O}_{3}=6$ [2].

It was discovered that the nature of the alkali activators determine the pore size of geopolymer. Geopolymers generally have microporous frameworks which depend on the nature of the alkali cation or mixture of cations used in activation. Fly ash-based geopolymer shows quartz and mullite particles that act as micro-aggregates in the final matrix, with evidence of unreacted glassy aluminosilicates.

Geosynthesis or geopolymerization are generally performed by reaction of an aluminosilicate powder with an alkaline silicate solution at roughly ambient conditions yielding polymeric $\mathrm{Si}-\mathrm{O}-\mathrm{Al}-\mathrm{O}$ bonds, as described by the formula below

$$
\mathrm{M}_{\mathrm{n}}\left[-\left(\mathrm{Si}-\mathrm{O}_{2}\right)_{\mathrm{z}}-\mathrm{Al}-\mathrm{O}\right]_{\mathrm{n}} \cdot \mathrm{wH}_{2} \mathrm{O}
$$

(Where $\mathrm{M}$ is an alkaline element, the symbol "." indicate presence of a bond, $\mathrm{z}$ is 1,2 or 3 , and $\mathrm{n}$ is degree of polymerization) Geopolymer product formed may be amorphous or semi-crystalline in structure depending on the temperature of geopolymerization $[1,11,12]$.

Metakaolin is a commonly used starting material for laboratory synthesis of geopolymer binder or cement, and is generated by thermal activation of kaolinite clay. The thermal activation of clay minerals is in the temperature range between 500 and $800^{\circ} \mathrm{C}$ results generally in the dehydroxylation of the clay mineral. The octahedral sheet loses water and decomposes into a disordered meta state in case of collapsing clay minerals [13]. The meta stable state of the collapsing clay is generally known to be reactive as pozzolana [14-19]. Firing the clay to higher temperatures results in the formation of new phases such as spinel and mullite [10, 20, 21].

Most studies have proven the utilization of secondary (waste) resources in the synthesis of geopolymer cements or concretes. Such materials include fly ash or lava from coal, slag [21-24] etc.

The reaction mechanism of geopolymerisation or geosynthesis follows a multi steps process:

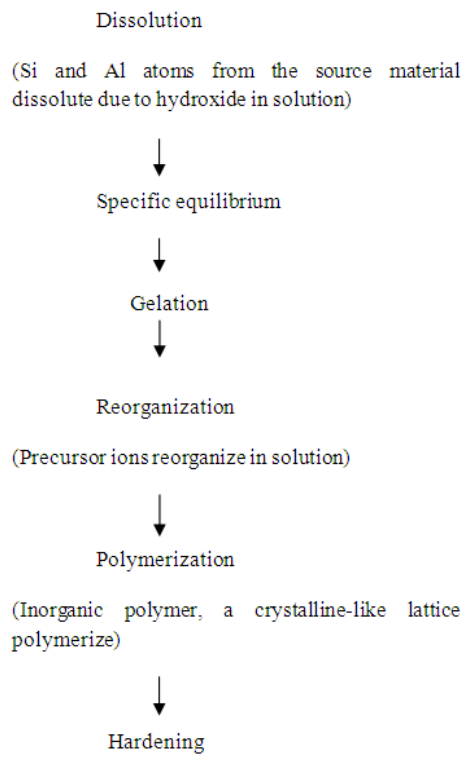

These processes occur simultaneously.

The inorganic polymer network formed is in general, a 
highly-coordinated 3-dimensional aluminosilicate gel, with the negative charges on tetrahedral Al (III) sites chargebalanced by alkali metal cations.

This paper describes different materials suitable for procurement of geopolymer and reviews the trend in the compressive strength and water absorption of different types of synthesized geopolymers.

\section{Fly Ash Based Geopolymer}

\subsection{Fly Ash}

Fly ashes are fine and glassy powder that are recovered as a result of coal combustion during production of electricity. It is being regarded as Coal Combustion Waste. Composition of fly ash depends on fly ash source, but all fly ashes includes substantial amounts of silicon dioxide $\left(\mathrm{SiO}_{2}\right)$ which is present in two forms: amorphous, which is rounded and smooth, and crystalline, which is sharp, pointed, calcium oxide $(\mathrm{CaO})$, aluminum oxide $\left(\mathrm{Al}_{2} \mathrm{O}_{3}\right)$ and iron oxide $\left(\mathrm{Fe}_{2} \mathrm{O}_{3}\right)$. Magnesium, potassium, sodium, titanium, and sulphur are also present in lesser amount [28]. Fly ash particles are generally spherical in shape and range in size from $0.5 \mu \mathrm{m}$ to $100 \mu \mathrm{m}$. Fly ashes are generally highly heterogeneous, consisting of a mixture of glassy particles with various identifiable crystalline phases such as quartz, mullite and various iron oxides $[25,26]$. Two main types of fly ashes: Class F fly ash and Class C fly ash exist. Table 1 summarizes the distinct difference in properties and composition of class $\mathrm{C}$ fly ash and class F fly ash. The chief difference between these classes is the amount of calcium, silica, alumina, and iron content in the ash. Source of coal always determine the chemical composition of the fly ash [24].Figure 2 and 3 show images of Class C and Class F fly $\operatorname{ash}[27]$.

Burning of harder, older anthracite and bituminous coal typically produces Class F fly ash while Class C fly ash result from combustion of younger lignite or sub bituminous coal. Class $\mathrm{F}$ fly ash has been investigated to contains less than $20 \% \mathrm{CaO}$ while Class $\mathrm{C}$ fly ash contains more than $20 \% \mathrm{CaO}$ [28].

Table 1. Typical differences in properties and composition of class $C$ fly ash and class F fly ash.

\begin{tabular}{lll}
\hline Properties/Composition & Class C Fly Ash & Class F Fly Ash \\
\hline & Very effective; & Effective; \\
Early strengths (<28 days) & Can replace cement & May replace \\
& $1: 1$ & $1: 2$ \\
Reduce Permeability & Effective & Very effective \\
Quartz & Found & Found \\
Resistance to sulfate attack & Less effective & Very effective \\
Mullite & Not found & Found \\
Tricalcium & Found & Not found \\
Aluminate & Not found & Found \\
\hline
\end{tabular}

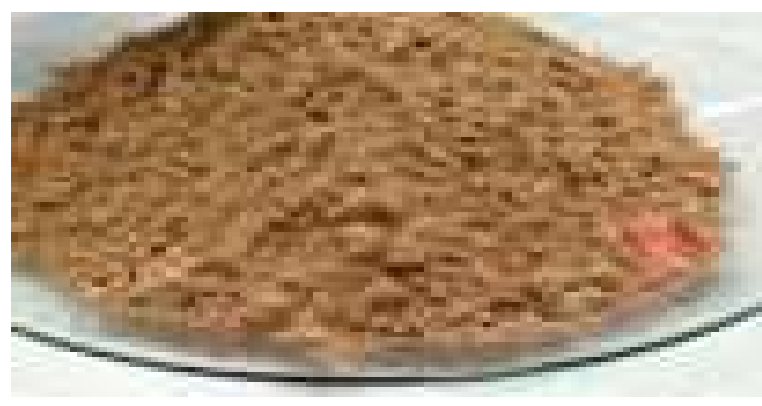

Figure 2.Class C Fly ash [27]

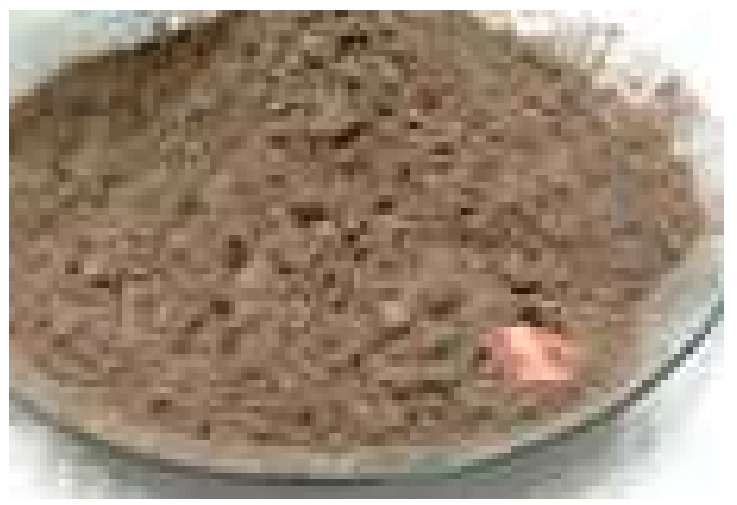

Figure 3. Class F Fly ash [27]

Fly ash has been proven to be one of the starting materials in the synthesis of geopolymer. Scott[29] et al confirm the usability of fly ash in the procurement of geopolymer.

Fly ash based geopolymer is generally synthesized by preparing a solution of sodium hydroxide and potassium hydroxide separately then added to the liquid commercial sodium silicate (water glass); this solution may then be added to the powdered fly ash, the same way water is add to Portland cement. Follow by curing at a temperature ranging between $60^{\circ} \mathrm{C}$ and $90^{\circ} \mathrm{C}$ depending on the properties of the fly ash used [30 \&31].

Oh Jae et al., [32] reported the compressive strength (14 days compressive strength) of the two main types of fly ash based geopolymer. Author reported that "the major difference in chemical composition between the high strength and low strength samples is the calcium content of the raw materials. In the absence of sodium hydroxide, it was clearly observed that the use of water glass immediately reduced the Workability of Ca-rich sample paste, leading to a large reduction in the compressive strength. In the presence of sodium hydroxide, the addition of water glass largely enhanced the compressive strength in Ca-rich fly ash pastes".

The study also reviewed that high calcium content in Class C fly ash seems to reduce the compressive strength of the synthesized geopolymer.

Suresh et al., [33] manufactured geopolymer mortal with Class F fly ash and varied the percentage of alkali activator. The study reviewed out that geopolymer mortar specimens manufactured by activation with higher alkali content $\left(\% \mathrm{Na}_{2} \mathrm{O}\right)$ resulted in lower water absorption, apparent 
porosity and water sorptivity and high compressive strength (28 days compressive strength). Residual compressive strength after exposure in sulphuric acid had a direct relationship with alkali content. Specimens with higher alkali content recorded higher residual compressive strength.

Anurag et al [34] conducted an experiment on fly ash based geopolymer concrete by varying the concentration of $\mathrm{NaOH}$ and curing time. Compressive strength (28 days compressive strength), water absorption and tensile strength tests were conducted on each of the samples. Results of the investigation indicated that there was an increase in compressive strength with increase in $\mathrm{NaOH}$ concentration. Strength was also increased with increase in curing time, although the increase in compressive strength after $48 \mathrm{hrs}$ curing time was not significant.

\section{Metakaolin Based Geopolymer}

Metakaolin is produced by firing Kaolin clay under carefully controlled conditions to create an amorphous aluminosilicate that is reactive in concrete [35].Figure 4 shows the image of metakaolin [36].

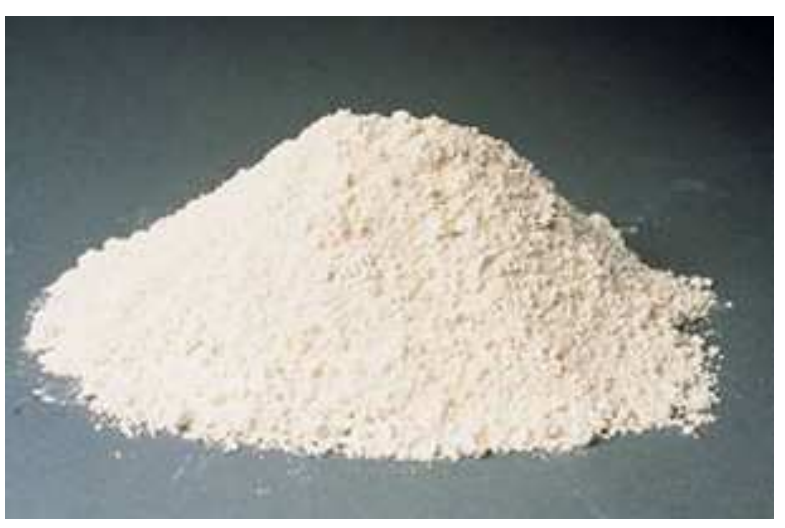

Figure 4. Metakaolin image [36]

Kaolinite clay minerals lose most of their adsorbed water at $100-200^{\circ} \mathrm{C}$. Between $500-800^{\circ} \mathrm{C}$ kaolinite becomes calcined by losing water through dehydroxilization. The dehydroxilization of kaolin to metakaolin is an endothermic process due to the large amount of energy required to remove the chemically bonded hydroxyl ions. Above this temperature range, kaolinite becomes metakaolin, with a two-dimensional order in crystal structure. Many merits have been reported on the uses of metakaolin as raw material in the synthesis of geopolymer. These include reduction of efflorescence (a whitish haze which is caused when a calcium hydroxide reacts with carbon dioxide in the atmosphere), increase or boost compressive and flexural strengths, mitigate against chloride and other permeability, increase resistance to acid attack and durability of the geopolymer. Metakaolin is known to contain large percentage of $\mathrm{SiO}_{2}$ and $\mathrm{Al}_{2} \mathrm{O}_{3}$ [37-39]. Several scientists have synthesized geopolymer using metakaolin as the starting material.
Andrea and Harald [40] used two methods in synthesis of metakaolin based geopolymer. In their first method, sodium hydroxide and water glass were mixed and metakaolin was poured without allowing the mixture to cool. Curing was later done at ambient temperature. In the second mixture, cooling of the sodium hydroxide and water glass was done before addition of the metakaolin. The whole mixture was cured at a temperature of $60^{\circ} \mathrm{C}$ and above. Compressive strength and water absorptivity were performed on the synthesized metakaolin based geopolymer.

Andrea and Harald [40] concluded that "Processing at ambient temperature may be unfeasible due to a delayed beginning of setting. A thermal treatment can avoid the delayed and yield a rapid strength development. Curing at $75^{\circ} \mathrm{C}$ for 4 hours resulted in satisfactory properties and the geopolymer formed does not need any special secondary treatment".

Table $3 \& 4$, showing compressive strengths for the synthesized geopolymer after thermal treatment at $60^{\circ} \mathrm{C}$, $75^{\circ} \mathrm{C}$ and $90^{\circ} \mathrm{C}$ for 2 and 4 hours, respectively, and storage at ambient conditions and under water, respectively, until testing after 7 and 28 days[40].

Ferone et al., synthesized metakaolin based geopolymeric mortar using four geopolymer formulations, obtained by varying the composition of the activating solution in terms of $\mathrm{SiO}_{2} / \mathrm{Na}_{2} \mathrm{O}$ ratio[41].

Table 3. Showing tensilestrength for the synthesized geopolymer after for 2 and 4 hours and storage at ambient conditions under water until testing after 7 days [40]

\begin{tabular}{rcccccc}
\hline & \multicolumn{3}{c}{ Ambient Conditions } & \multicolumn{3}{c}{ Under Water } \\
\hline $\mathrm{T}{ }^{\circ} \mathrm{C}$ & 60 & 75 & 90 & 60 & 75 & 90 \\
$\mathrm{TS} 2$ & 31.3 & 28.9 & 30.3 & 31.1 & 22.3 & 31.4 \\
$\mathrm{TS} 4$ & 30.6 & 34.0 & 32.1 & 25.0 & 28.8 & 19.9 \\
\hline
\end{tabular}

T represents temperature, TS2 represents tensile strength performed after 2 days and TS4 represents tensile strength performed after 4 days in $\mathrm{MPa}$

Table 4. Showing tensile strength for the synthesized geopolymer after for 2 and 4 hours and storage at ambient conditions under water until testing after 14 days [40]

\begin{tabular}{ccccccc}
\hline & \multicolumn{3}{c}{ Ambient Conditions } & \multicolumn{3}{c}{ Under Water } \\
\hline $\mathrm{T}\left({ }^{\circ} \mathrm{C}\right)$ & 60 & 75 & 90 & 60 & 75 & 90 \\
$\mathrm{TS} 2$ & 37.8 & 29.4 & 36.9 & 34.4 & 18.4 & 25.1 \\
$\mathrm{TS} 4$ & 34.3 & 39.8 & 32.8 & 28.7 & 28.2 & 26.7 \\
\hline
\end{tabular}

T represents temperature, TS2 represents tensile strength performed after 2 days and TS4 represents tensile strength performed after 4 days in $\mathrm{MPa}$

The compositions of geopolymers were formulated to ensure that the $\mathrm{Al} / \mathrm{Na}$ ratio is constant at 1 , sufficient alkali was provided to enable complete charge balancing of the negatively charged tetrahedral aluminum centers. Sodium silicate solutions characterized by molar $\mathrm{SiO}_{2} / \mathrm{Na}_{2} \mathrm{O}$ ratio $(r)$ of $0,0.67,1.34$ and 1.67 , and molar $\mathrm{H}_{2} \mathrm{O} / \mathrm{Na}_{2} \mathrm{O}$ ratio of 10.5 , were prepared by using a $10 \mathrm{M} \mathrm{NaOH}$ solution $(r=0)$, adding a $15 \mathrm{M} \mathrm{NaOH}$ solution to the sodium silicate 
solution No. $1(r=0.67)$, or dissolving solid sodium hydroxide into the sodium silicate solution No. 1 or No. 2 ( $r=1.34$ and $r=1.67$, respectively). This resulted in a total of four different specimens compositions with nominal chemical composition $\mathrm{Na}_{2} \mathrm{O} \cdot\left(\mathrm{SiO}_{2}\right) z \cdot \mathrm{Al}_{2} \mathrm{O}_{3} \cdot 10.5 \mathrm{H}_{2} \mathrm{O}$, where $z$ is $2.15,2.80,3.50$ and 3.80 . The four mixtures were coded as 1.07, 1.40, 1.75 and 1.90, respectively, according to their $\mathrm{Si} / \mathrm{Al}$ ratio. Table 5 shows the parameters of the prepared mixtures [41]

Table 5. Synoptic table of the prepared mixtures [41]

\begin{tabular}{|c|c|c|c|c|}
\hline sample & 1.07 & 1.40 & 1.75 & 1.90 \\
\hline $\mathrm{r}$ & 0 & 0.67 & 1.34 & 1.67 \\
\hline \multirow{4}{*}{$\begin{array}{l}\text { Chemical } \\
\text { compositi } \\
\text { on }\end{array}$} & $\mathrm{Na}_{2} \mathrm{O} \cdot\left(\mathrm{SiO}_{2}\right)$ & $\mathrm{Na}_{2} \mathrm{O} \cdot\left(\mathrm{SiO}_{2}\right)$ & $\mathrm{Na}_{2} \mathrm{O} \cdot\left(\mathrm{SiO}_{2}\right)$ & $\mathrm{Na}_{2} \mathrm{O} \cdot\left(\mathrm{SiO}_{2}\right)$ \\
\hline & 2.15 & 2.80 & 3.50 & 3.80 \\
\hline & $\mathrm{Al}_{2} \mathrm{O}_{3} \cdot\left(\mathrm{H}_{2} \mathrm{O}\right)$ & $\mathrm{Al}_{2} \mathrm{O}_{3} \cdot\left(\mathrm{H}_{2} \mathrm{O}\right)$ & $\mathrm{Al}_{2} \mathrm{O}_{3} \cdot\left(\mathrm{H}_{2} \mathrm{O}\right)$ & $\mathrm{Al}_{2} \mathrm{O}_{3} \cdot\left(\mathrm{H}_{2} \mathrm{O}\right)$ \\
\hline & 10.5 & 10.5 & 10.5 & 10.5 \\
\hline $\begin{array}{c}\text { Mix } \\
\text { design (g) }\end{array}$ & - & - & - & - \\
\hline $\begin{array}{l}\text { Sodium } \\
\text { silicate }\end{array}$ & - & 60(No.1) & 120 (No.1) & 139 (No.2) \\
\hline $\begin{array}{c}\text { Solid } \\
\mathrm{NaOH}\end{array}$ & - & - & 20 & 6.3 \\
\hline $\begin{array}{c}\mathrm{NaOH} \\
(\mathrm{aq})\end{array}$ & $110(10 \mathrm{M})$ & $64(15 \mathrm{M})$ & - & - \\
\hline $\begin{array}{c}\text { metakaoli } \\
\mathrm{n}\end{array}$ & 100 & 100 & 100 & 100 \\
\hline
\end{tabular}

Result of his experiment shows that curing of metakaolin based geopolymers at ambient can lead to material shrinkage. This issue was related to the amount of evaporable water of the sample,which was found to increase with the $\mathrm{Si} / \mathrm{Al}$ ratio of the geopolymer mixture.

Figure 5 shows the variation of the parameter W (weight \%) versus the $\mathrm{Si} / \mathrm{Al}$ ratio. It is evident that the percentageof evaporable water linearly increases with the $\mathrm{Si} / \mathrm{Al}$ ratio. The higher percentage of evaporable water of the samples characterized by higher $\mathrm{Si} / \mathrm{Al}$ ratios accounts for their higher sensitivity to drying shrinkage

He then concluded that a medium-high value of $\mathrm{Si} / \mathrm{Al}$ ratio was found to be the best compromise between mechanical performances and shrinkage issues [41].

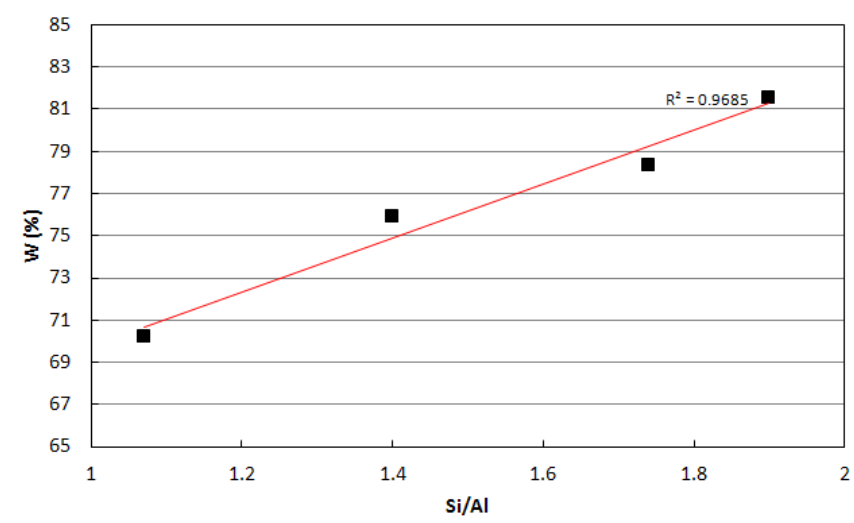

Figure 5. W parameter of samples 1.07, 1.40, 1.75 and 1.90[38]

Gougazeh worked on four metakaolin materials namely Jordanian metakaolin, Metastar 501 metakaolin, Fluka metakaolin and mixed Fluka metakaolin with quartz, to investigate the influence of chemical and mineralogical compositions on thecompressive strength of geopolymers synthesized by alkali activation of metakaolin. The procured geopolymer cements were aged at $25^{\circ} \mathrm{C}$ between 24 and 672 hours. The influence of secondary phase (quartz) on the geopolymerization reaction of metakaolin was also investigated by comparing the four metakaolins.

Author reportedthat quartz, at the concentration used, does not prevent the geopolymerization reaction. On the other hand, in the case of Jordanian metakaolin and mixed Fluka metakaolin with quartz, the geopolymerproducts form a cohesive and relatively hard solid indicating that they have large and stable compressivestrength compared with the other two metakaolins (Fluka and Metastar 501 Metakaolins) [42].

\section{Clay Based Geopolymer}

\subsection{Clay and its Properties}

Clay is a naturally occurring aluminum silicate composed primarily of fine-grained minerals. Clay is much smaller than sand and silt particles. It imparts plasticity and hardens when fired or dried. Clay may undergo either hydration or dehydration in response to environmental condition (wet and dry conditions). It also may contain variable amounts of water trapped in the mineral structure by polar attraction (great affinity for water) and easily disperses in water to form good slurry. Some swell easily and may double in thickness when wet. Most have the ability to soak up ions (electrically charged atoms and molecules) from a solution and release the ions later when conditions change. This is due to the charged surface of clay minerals [43].

\subsection{Mineralogy of Clay}

Clay minerals have a wide range of particle sizes from 10 's of angstroms to millimeters [44].

\subsubsection{Kaolinite}

Kaolinite is a white hydrated aluminum silicate crystalline mineral. It is a soft powder that has a fine particle and plate-like in appearance.

Kaolin as a name is derived from a hill in China (Kaolin) where it is being mined for centuries. It is formed over millions of years by the hydrothermal decomposition of granite rocks[45]. Kaolin is also found in Africa especially Nigeria. It a major natural resource found in Kankara local Government, Kastina State (Nigeria) Researches conducted by various mining experts have certified Kankara kaolin as one of the best and cleanest mineral resources that lies beneath Kankara soil [46,47]. Lori et al., characterized kankara clay with x-ray diffraction and result shown that kaolinite is the dominant mineral phase with minor amounts of quartz, goethite and muscovite. The diffraction pattern of the glycolated clay sample did not indicate the presence of mixed layer clay swelling clay such as 
smectites [47].

\subsubsection{Montmorillonite-Smectite}

Montmorillonite-smectite is a very small platy, micaceous crystals, usually opaque with variable water content. Chemically, it is made up of hydrated sodium calcium aluminum magnesium silicate hydroxide.

It is named after Montmorillon in France. Structurally, montmorillonite is informed of a two tetrahedral sheets sandwiching a central octahedral sheet [44].

\subsubsection{Illite}

Illite is a form of muscovite that is non-expanding and which contains alumino-silicate in larger amount.

Its structure is constituted by the repetition of tetrahedron - octahedron - tetrahedron (TOT) layers [48]. Several scientists have worked on clay for procurements of both polymers and geopolymers. Hegde et al., reported the effect of nanoclay additive on the structure, morphology, and mechanical properties of polypropylene melt blown webs [49]. In 2012, Hegde et al., also presents the effect of increasing weight percentage natural nanoclay additives on the structure, morphology and mechanical properties of nylon-6-blown films [50].

\section{Kaolin Based Geopolymer}

Yunsheng Zhanget al [51] studied the influence of these three key parameters " $\mathrm{SiO}_{2} / \mathrm{Al}_{2} \mathrm{O}_{3}, \mathrm{M}_{2} \mathrm{O} / \mathrm{Al}_{2} \mathrm{O}_{3}, \mathrm{H}_{2} \mathrm{O} / \mathrm{M}_{2} \mathrm{O}$ " on the synthesis of calcined kaolin-based geopolymer. Where $\mathrm{M}$ symbolized $\mathrm{Na}$ ion or $\mathrm{K}$ ion. A total of 9 cement pastes with different mole ratios $\mathrm{SiO}_{2} / \mathrm{Al}_{2} \mathrm{O}_{3}, \mathrm{Na}_{2} \mathrm{O} / \mathrm{Al}_{2} \mathrm{O}_{3}$, $\mathrm{H}_{2} \mathrm{O} / \mathrm{Na}_{2} \mathrm{O}$ were designated to investigate the effects on mechanical strength. The gradation analysis of experimental results that were obtained revealed that $\mathrm{Na}_{2} \mathrm{O} / \mathrm{Al}_{2} \mathrm{O}_{3}$ and $\mathrm{H}_{2} \mathrm{O} / \mathrm{Na}_{2} \mathrm{O}$ had significant impact on the compressive strength. The highest compressive strength (34.9 $\mathrm{MPa}$ ) was achieved at $\mathrm{SiO}_{2} / \mathrm{Al}_{2} \mathrm{O}_{3}=5.5, \mathrm{Na}_{2} \mathrm{O} / \mathrm{Al}_{2} \mathrm{O}_{3}=$ 1.0 and $\mathrm{H}_{2} \mathrm{O} / \mathrm{Na}_{2} \mathrm{O}=7.0$. This formulation was regarded as fully reacted geopolymer cement.

Qhat and Nasser [52] chemically and mineralogically characterized different clays. Table 6 reported the mineralogy of the different clays that was determined using $\mathrm{XRD}$. Based on their experiment, clays were calcinated at $700^{\circ} \mathrm{C}$ for 2 hours. $\mathrm{NaOH}$ solution or alkaline sodium silicate solutions were used as activators. The curing step was performed at different temperatures (room temperature, $75^{\circ} \mathrm{C}$ and $150^{\circ} \mathrm{C}$ ). Amorphous geopolymer phase was formed at all processing temperatures. Their investigation reviewed that the mechanical properties of the geopolymers depended on amounts of active aluminum silicates in the starting material, the type of activator and the processing temperature. The results showed that two of the studied clays have adequate characteristics for geopolymer brick manufacture when activated with $\mathrm{NaOH}$ solution. However, all studied clays were suitable for geopolymer brick manufacture if activated with sodium silicate solution.
Water absorption test were carried out on the geopolymeric bricks. Table 7 summarizes the result of the absorption test.

Table 6. Mineralogical composition of different clays and pure kaolin [52]

\begin{tabular}{lllll}
\hline Phase & Kaolin & $\begin{array}{l}\text { White } \\
\text { clay }\end{array}$ & $\begin{array}{l}\text { Grey } \\
\text { clay }\end{array}$ & $\begin{array}{l}\text { Red } \\
\text { clay }\end{array}$ \\
\hline & $($ KA) & $(\mathbf{W C})$ & $(\mathbf{G C})$ & $(\mathbf{R C})$ \\
Kaolinite $\left(\mathrm{Al}_{2} \mathrm{Si}_{2} \mathrm{O}_{5}(\mathrm{OH})_{4}\right)$ & 84 & - & 32 & 40 \\
Illite $\left(\mathrm{K}_{0.8} \mathrm{Al}_{2}\left(\mathrm{Si}_{3.2} \mathrm{Al}_{0.8}\right) \mathrm{O}_{10}(\mathrm{OH})_{2}\right)$ & 16 & - & - & - \\
Montmorillonite $\left(\mathrm{Al}_{2} \mathrm{Si}_{4} \mathrm{O}_{11} \cdot \mathrm{H}_{2} \mathrm{O}\right)$ & - & 30 & 8 & 12 \\
Calcite $\left(\mathrm{CaCO}_{3}\right)$ & - & - & 15 & - \\
Quartz $\left(\mathrm{SiO}_{2}\right)$ & - & 70 & 15 & 18 \\
Hematite $\left(\mathrm{Fe}_{2} \mathrm{O}_{3}\right)$ & - & - & 2 & 4 \\
Albite $\left(\mathrm{NaAlSi}_{3} \mathrm{O}_{8}\right)$ & - & - & 7 & 26 \\
Microcline $\left(\mathrm{KAlSi}_{3} \mathrm{O}_{8}\right)$ & - & - & 13 & - \\
\hline
\end{tabular}

Table 7. Water absorption (\%) of bricks processed at different temperature [52]

\begin{tabular}{lcccc}
\hline \multirow{2}{*}{ Activator } & & \multicolumn{3}{c}{ Processing temperature } \\
& Sample & Room & $\mathbf{7 5}^{\circ} \mathbf{C}$ & $\mathbf{1 5 0}^{\mathbf{}} \mathbf{C}$ \\
\hline \multirow{2}{*}{$\mathrm{NaOH}$} & $\mathrm{KA}$ & 8.2 & 7.5 & 8.6 \\
& $\mathrm{WC}$ & 11.3 & 10.6 & 10.8 \\
& $\mathrm{GC}$ & 9.8 & 9.4 & 9.5 \\
& $\mathrm{RC}$ & 9.5 & 9.2 & 9.7 \\
$\mathrm{NaOH}+\mathrm{Na}$ & $\mathrm{KA}$ & 5.3 & 5.1 & 5.1 \\
Silicate & $\mathrm{WC}$ & 6.8 & 5.8 & 5.5 \\
& $\mathrm{GC}$ & 6.4 & 5.1 & 5.0 \\
& $\mathrm{RC}$ & 5.6 & 4.8 & 4.8 \\
\hline
\end{tabular}

\section{Discussion}

\subsection{Comprehensive Strength}

Compressive or tensile strength is the capacity of a material or structure to withstand loads tending to reduce size. In table 2, comparing the comprehensive strength of class $\mathrm{F}$ fly ash and class $\mathrm{C}$ fly ash cured at $80 \mathrm{oC}$ for 14 days. Class F fly ash gives greater comprehensive strength. This can be best explained by the fact that class f fly ash has less percentage of $\mathrm{CaO}$, which promote the strength of the bricks. Also, curing class F fly ash at $600 \mathrm{C}$ for 28 days gives the best comprehensive strength and this can be viewed as the best parameters for curing class $\mathrm{F}$ fly ash.

Table 2. Showing the compressive strength of different class of fly ash

\begin{tabular}{|c|c|c|c|}
\hline Sample & $\begin{array}{l}\text { Curing } \\
\text { Temperature }\left({ }^{\circ} \mathrm{C}\right)\end{array}$ & $\begin{array}{l}\text { Compressive } \\
\text { Strength (MPa) }\end{array}$ & Author \\
\hline $\begin{array}{l}\text { Class C Fly } \\
\text { Ash (FAC) }\end{array}$ & 80 & 17.6/14-day & Oh et al \\
\hline $\begin{array}{l}\text { Class F Fly } \\
\text { Ash (FAF) }\end{array}$ & 80 & 38/14-day & Oh et al \\
\hline $\begin{array}{l}\text { Class F Fly } \\
\text { Ash (FAF) }\end{array}$ & 85 & 40/28-day & $\begin{array}{l}\text { Suresh et } \\
\text { al }\end{array}$ \\
\hline $\begin{array}{l}\text { Class F Fly } \\
\text { Ash (FAF) }\end{array}$ & 60 & 46/28-day & $\begin{array}{l}\text { Anurag et } \\
\text { al }\end{array}$ \\
\hline
\end{tabular}

Both Andrea \& Haraldand Ferone et al confirmed the usability of metakaolin as the starting material for geopolymers, their works reviewed that curing metakaolin at ambient temperature may delay the strength development and result into drying shrinkage. Result from table 3 and 4 
indicate that, curing geopolymer at temperature other than room temperature lead to high comprehensive strength. Curing metakaolin based geopolymer at $75^{\circ} \mathrm{C}$ for 4 hours resulted in satisfactory properties irrespective of the method embark on during activation.

It is clear that the chemistry of geopolymer depends on the activators. $\mathrm{NaOH}$, water glass and mixture of $\mathrm{NaOH}$ and water glass can be use independently as activator for synthesizing geopolymers. Generally, bricks activated with a mixture of alkaline sodium silicate solutions attain much higher strengths than those activated with only $\mathrm{NaOH}$ solutions. In table 7, water absorption for geopolymers activated with $\mathrm{NaOH}+\mathrm{Na}$ Silicate decreases compare with the geopolymers activated with $\mathrm{NaOH}$ solution only. The difference arises from the use of water glass which enhances dissolution of and activates aluminum silicate constituents of the starting materials thereby promoting high compressive strength.

\subsection{Water Absorption}

Water absorption is avital property that stimuli the longevity of bricks. The lower water absorbed into geopolymeric bricks the higher the resistance to water infiltration and the lower the environmental damage caused on the bricks.

Table 8. ASTM Specifications for different bricks and load-bearing concrete masonry units [51]

\begin{tabular}{lllll}
\hline $\begin{array}{l}\text { Title of } \\
\text { specificatio } \\
\mathbf{n}\end{array}$ & $\begin{array}{l}\text { ASTM } \\
\text { designatio } \\
\mathbf{n}\end{array}$ & $\begin{array}{l}\text { Weatherin } \\
\text { g } \\
\text { conditions }\end{array}$ & $\begin{array}{l}\text { Minimum } \\
\text { compressiv } \\
\text { e strength } \\
\text { (MPa) }\end{array}$ & $\begin{array}{l}\text { Maximum } \\
\text { water } \\
\text { absorptio } \\
\text { n (\%) }\end{array}$ \\
\hline $\begin{array}{l}\text { Building } \\
\text { brick }\end{array}$ & C62 & SW & 20.7 & 17 \\
& & MW & 17.2 & 22 \\
Facing brick & C216 & NW & 10.3 & No limit \\
Pedestrian & & NW & 20.7 & 17 \\
$\begin{array}{l}\text { and light } \\
\text { traffic }\end{array}$ & C902 & SW & 17.2 & 22 \\
paving brick & & MW & 55.2 & 8 \\
$\begin{array}{l}\text { Load } \\
\text { bearing }\end{array}$ & & NW & 20.7 & 14 \\
$\begin{array}{l}\text { masonry } \\
\text { units }\end{array}$ & C90 & & & No limit \\
\hline
\end{tabular}

SW indicates severe weathering, MW indicates moderate weathering, and NW indicates negligible or no weathering

According to the ASTM Specifications [54] for different bricks and load-bearing concrete masonry units in table 8 , the maximum water absorption for a building bricks is $17 \%$. Therefore any geopolymeric bricks having its water absorption greater than this value cannot be used for building purposes. Water absorption test values reported in table7 were lower than the ASTM Specification. Meaning that, bricks from geopolymer can be used for construction purposes. Also in table 7, geopolymers activated with $\mathrm{NaOH}+\mathrm{Na}$ Silicate have lower water absorption values than those activated with only $\mathrm{NaOH}$ solution. From this, one can infer that addition of water glass ( $\mathrm{Na}$ silicate) enhances the rate of strength development of the synthesized geopolymer.

\section{Conclusion}

The following conclusions were drawn from the review study on geopolymers:

- Procurement of geopolymer is possible with any alumino-silicate materials.

- Compressive strength increases with increase in concentration of sodium silicate as well as sodium hydroxide.

- The addition of water glass enhances the rate of strength development of the synthesized geopolymer by promoting the hydrolysis of the siliceous and aluminum species of the raw materials.

- Addition of water glass can also compensate shortage of silicate in the raw materials.

- Water absorptivity of any geopolymer decreases with increase in concentration of sodium hydroxide or water glass.

- Water absorptivity of geopolymer also decreases with increase in duration of the geopolymer curing time.

\section{References}

[1] J. Davidovits, "Solid phase synthesis of a mineral block polymer by low temperature polycondensation of aluminosilicate polymers", IUPAC International Symposium on Macromolecules Stockholm; Sept. Topic III, New Polymers of high stability, 1976.

[2] R. Cioffi, L. Maffucci and L. Santoro "Optimization of geopolymer synthesis by calcinations and polycondensation of a kaolinitic residue Resources", Conservation and Recycling, 40, pp. 27-38, 2003.

[3] R. Sathia K.G. Babu and M. Santhanam, "Durability study of lowcalcium fly ash geopolymer concrete", The $3^{\text {rd }}$ ACF International Coference-ACF/VCA, 2008.

[4] T. Bakharev, "Thermal behaviour of geopolymers prepared usingclass F fly ash and elevated temperature curing", Cement ConcreteRes., 36: 1134-1147,2006.

[5] S. Thokchom, P. Ghosh and S. Ghosh, "Performance of Fly ash Based Geopolymer Mortars in Sulphate Solution", J. Eng. Tech. Rev., 3,1:36-40, 2010.

[6] M.W. Barsoum, M and A. Ganguly. "Microstructural Evidence of Reconstituted Limestone Blocks in the Great Pyramids of Egypt." Journal of the American Ceramics Society, 89, 2006.

[7] D.L.Y. Kong andJ.G. Sanjayan,"Effect of elevated temperaturesgeopolymer paste, mortar and concrete", Cement Concrete Res., 40;334-339, 2010.

[8] P.D. Silva,K. Sagoe-Crenstil andV. Sirivivatnanon,"Kinetics of geopolymerization: Role of $\mathrm{Al}_{2} \mathrm{O}_{3}$ and $\mathrm{SiO}_{2}$ " Cement Concrete Res 37:512-518, 2007.

[9] D. Roy, "Alkali-activated cements opportunities and 
challenges", CemConcr Res, 29, pp. 249-254, 1999.

[10] E. Mendelovici, "Comparative study of the effects of thermal and mechanicaltreatments on the structures of clay minerals", Journal of Thermal Analysis 49,3, pp.1385-1397, 1997

[11] D. Dimas, I. Giannopoulou and D. Panias,"Polymerization in sodium silicate solutions: afundamental process in geopolymerizationtechnology", J. Mater Sci44, pp. 37193730,2009

[12] D.Hardjito, S.E. Wallah,D.M.J. Sumajouw and B.V. Rangan, "Factors influencing thecompressive strength of fly ash-based geopolymerconcrete" DimensiTeknikSipil6, 2, pp. $88-93,2004$

[13] G. Baronio and L. Binda, "Study of the pozzolanity of some bricks and clays", Construction and Building Materials 11 , pp. 41-46, 1997.

[14] C. He, B. Osbæck, E. Makovicky, "Pozzolanic reactions of six principal clay minerals: activation, reactivity assesments and technological effects". Cement and Concrete Research 25 8, pp.1691-1702. 1995a

[15] C. He, B. Osbæck and E. Makovicky, "Thermal stability and pozzolanic activity of calcinedillite", Applied Clay Science 9 pp.337-354, 1995b.

[16] C. He, B. Osbæck and E. Makovicky, "Thermal stability and pozzolanic activity of raw and calcined mixed-layer mica/smectite" Applied Clay Science 17 pp.141-161, 2000.

[17] G. Kakali, T. Perrak, S. Tsivilis and E. Badogiannis, "Thermal treatment of kaolin: the effect of mineralogy on the puzzolanic activity", Applied Clay Science 20 pp.73- 80, 2001.

[18] E. Liebig and E. Althaus, "Kaolinit und montmorillonitalspuzzolanischekompo- nenten in kalkmörteln", ZKG International 50, 5, pp. 282-290, 1997.

[19] B.B. Sabir, S. Wild and J. Bai, "Metakaolin and calcined clays as pozzolans for concrete: a review", Cement and Concrete Composites, 23, 6, pp.441-454, 2001.

[20] K.J.D. MacKenzie, "Applications of solid state NMR spectroscopy to ceramic research", British Ceramic Transactions, 99,5, pp.231-240, 2000.

[21] J. McManus, S.E. Ashbrock and K.J.D. MacKenzie. "Wimperis S. 27Al multiple- Quantum MAS and27Al (1H) CPMAS NMR study of amorphous aluminosilicates". Journal of Non-Crystalline, 282, pp.278-290, 2001.

[22] A. Buchwald, "What are geopolymers? Current state of research and technology, the opportunities they offer, and their significance for the precast industry", Concrete Precasting Plant and Technology, 72, 7, pp.42-49, 2006.

[23] 15. P. Duxson, A. Fernández-Jiménez, J. Provis, G. Lukey, A Palomo and J. van Deventer,"Geopolymer technology: the current state of the art", Journal of Materials Science, 42, 9, pp. 2917-2933, 2007.

[24] A. Palomo, M.W. Grutzeck and M.T. Blanco, "Alkaliactivated fly ashes - a cement for the future", Cement and Concrete Research, 29, 8, pp. 1323-1329, 1999.

[25] D. Khale and R. Chaudhary,"Mechanism ofgeopolymerization and factors influencing itsdevelopment: a review"J Mater Sci10, pp. 729-746, 2007.

[26] F. Pacheco-Torgal,J. Castro-Gomes and S. Jalali, "Alkaliactivated binders: A review Part I.Historical background, terminology, reaction mechanisms and hydration products" J. Constr. BuildMater. 22, pp. 1305-1314, 2008.

[27] Kentuckey Educational site "What are Coal Combustion By-Products (CCBs)?", retrieved from http://www.caer.uky.edu/kyasheducation/flyash.shtml

[28] E.H Kim, "understanding effects of silicon/aluminum ratio and calcium hydroxide on chemical composition, nanostructure and compressive strength for metakaolin geopolymers," A thesis Submitted in partial fulfillment of the requirements for the degree of Master of Science in Civil Engineering in the Graduate College of the University of Illinois at Urbana-Champaign, 2012.

[29] A.N. Scott and M.D. Thomas, "Evaluation of Fly Ash from Co-Combustion of Coal and Petroleum Coke for Use in Concrete", ACI Materials Journal 104, 1, pp. 62-70, 2007.

[30] N.V. Chanh, B.D. Trung, B.D. andD.V. Tuan,"Recent research geopolymerconcrete", The $3^{\text {rd }} \mathrm{ACF}$ International Coference-ACF/VCA, 2008

[31] M. Komljenovi'c, Z. Bascarevic, and V. Bradic,"Mechanical andmicrostructural properties of alkali-activated fly ash geopolymer”,J.Hazardous Mater., 181: 35-42, 2010.

[32] E.O. Jae, J.M. Paulo, S.S Monteiro, S.C. Jun and M.C. Simon, "The evolution of strength and crystalline phases for alkali-activated ground blast furnace slag and fly ash-based geopolymers", Cement on concrete research 40, pp.189-196, 2010.

[33] T. Suresh, G. Partha and G. Somnath, "effect of water absorption, porosity and sorptivity on durability of geopolymer mortars", ARPN Journal of Engineering and Applied Sciences, 4 7, 2009.

[34] M. Anurag, C. Deepika, J. Namrata, Manish., S. Nidhi and D. Durga, "Effect of concentration of alkaline liquid and curing time on strength and water absorption of geopolymer concrete", ARPN Journal of Engineering and Applied Sciences, 3, 1, 2008 .

[35] G. Kakali,T. Perraki, S. Tsivilis andE. Badogiannis"Thermal treatment of kaolin: the effect of mineralogy on the pozzolanic activity",Applied Clay Science20: pp73-80,2001

[36] K. E. Kurtis, "Benefits of metakaolin in HPC" in concrete bridge view, 67, 2011.

[37] M. Bellotto,A. Gualtieri,A. Artioli andS.M. Clark "Kinetic study of the kaolinite-mullite reaction sequence". Physics and Chemistry of Minerals22: pp207-217, 1995.

[38] R. Fernandez,F. Martirena, andK.L. Scrivener "The origin of the pozzolanic activity of clay minerals: A comparison between kaolinite, illite and montmorillonite.".Cement and Concrete Research41: pp113-122, 2011.

[39] R. Snellings,G. Mertens andJ. Elsen "Supplementary cementitious materials". Reviews in Mineralogy and Geochemistry,74,pp. 211-278, 2012.

[40] V.K. Andrea and H. Harald, "investigation of geopolymer binders with respect to their application for building materials". Ceramics-Silikáty 48 3, pp. 117-120, 2004. 
[41] C. Ferone, F. Colangelo, G. Roviello, D. Asprone,C.Menna, A. Balsamo, A. Prota, R. Cioffiand G.Manfredi, "Application-oriented chemical optimization of a metakaolinbased geopolymer”, Materials6, 1920-1939, 2013.

[42] M.Gougazeh, "Geopolymers from Jordanian Metakaolin: Influence of Chemical andMineralogical Compositions on the Development of Mechanical Properties"Jordan Journal of Civil Engineering, 7, 2, 2013.

[43] S. Guggenheim and R.T. Martin, "Definition of clay and clay mineral: Journal report of the AIPEA nomenclature and CMS nomenclature committees", Clays and Clay Minerals, 43, pp. 255-256, 1995.

[44] F.J. Huertas, L. Chou andR. Wollast, "Mechanism of kaolinite dissolution at room temperatureand pressure" Part 1. Surface speciation. GeochimCosmochimActa, 62: 417 431, 1998.

[45] B.O. Aderemi, "Preliminary Studies on Synthesis of Zeolites from Local Clay, NigerianJournal of Scientific Research", 4,2: pp7-12, 2004.

[46] A.Y. Atta,O.A. Ajayi, and S.S. Adefila, "Synthesis of Faujasite Zeolites from Kankara Kaolin Clay", Journal of Applied Sciences Research, 3,10, pp1017-1021, 2007.

[47] J.A. Lori, A.O. Lawaland E. J. Ekanem "Characterisation and optimisation of deferration of kankara clay", ARPN Journal of Engineering and Applied Sciences, 2, 5, 2007
[48] D.D. Carr,L.F. Rooney andR.C. Freas,"Limestone and dolomite", In: Carr DD ed. Industrial minerals and rocks. Littleton, Colorado, Society for Mining, Metallurgy, and Exploration, pp606-629, 1994.

[49] R. Hegde, G.S. Bhat, Nanoparticle effects of structure and properties of melt blown webs, Journal of Applied Polymer Science, Volume 115, Pages 1062 - 1072, 2010.

[50] R. Hegde, G S. Bhat, B. Deshpande, Morphology and properties of nylon 6 blown films reinforced with different weight percentage of nanoclay additives, International Journal of Polymer Science, 2012.

[51] Y. Zhang, W. Sun, and Z. Li, "Composition design and microstructural characterization of calcined kaolin-based geopolymer cement", Applied Clay Science, 47, pp. 271275, 2010.

[52] A.M. Qhat, Y.M and Nasser, "Investigating the possibility of utilizing low kaolinitic clays in production of geopolymer bricks”, Ceramics - Silikáty, 54, 2, pp. 160-168, 2010.

[53] J. Davidovits"Geopolymer Chemistry and Applications. Institute Geopolymer, Saint-Quentin:France, 2nd Ed, pp. 32, 2008.

[54] ASTM C90, Standard specification for loadbearingconcrete masonry units, the American Society for Testingand Material, 2001 